\title{
SIPKADES (Sistem Informasi Potensi Kreatif Desa) Merintis Institusi Menjadi Mandiri : Belajar Mengelola Potensi Desa Bersama Teman Muda ${ }^{2}$
}

\begin{abstract}
ABSTRAK
Artikel ini bermaksud untuk mengurai pengalaman semasa belajar mengelola potensi desa bersama dengan teman - teman muda Brosot. Metode yang dilakukan dalam kegiatan ini adalah participatory action research di mana peneliti berposisi sebagai partner dalam merefleksikan kondisi yang mengitari teman - teman muda di Brosot. Pendekatan teoretik dalam praktik tersebut berlandaskan perangkat pikir institutional entrepreneurship yang memandang aktivitas entrepreneurship memiliki relasi bolak - balik yang intens dengan kecenderungan institusional yang bersinggungan. Tujuan akhir dari keseluruhan kegiatan ini adalah sebuah karya bersama yang dapat meningkatkan partisipasi teman - teman muda dalam pengambilan keputusan di level desa sekaligus mempersiapkan alternatif-kreatif bagi masa depan mereka.
\end{abstract}

Kata Kunci : Institutional Entrepreneurship, Pemuda, Participatory Action Research

\begin{abstract}
This article supposed to tell the earned experiences in learn managing rural area potentials along with the youth of Desa Brosot. Participation action research was used to be the main method so that both local youth and researchers were actively involved and build partnership. The theoretical approach in this research is institutional entrepreneurship which consider the entrepreneurship activities have intense reciprocal relations with the institutional tendency. The final intention through these activities is a work which can improve youth's participations in decision making process of their local rural governance as well as prepare options for their futures.
\end{abstract}

Keyword : institutional entrepreneurship, youth, participatory action research

\section{PENDAHULUAN}

Peluang kerja, kompetisi, dan tetek bengek soal masa depan masih menjadi perkara utama yang membikin keder warga muda di Indonesia (White, 2016; Nilan, 2013).
Terlebih lagi dikotomi di antara desa dan kota yang terus direproduksi dan menyebabkan harapan - harapan begitu terkutub ke gemerlap megapolitan. Dalam

\footnotetext{
${ }^{1}$ Penulis adalah asisten peneliti di Youth Studies Centre, Fakultas Ilmu Sosial dan Ilmu Politik Universitas Gadjah Mada. Dapat dihubungi via email yousure.fisipol@ugm.ac.id.

${ }^{2}$ Program ini dibiayai dengan Skema Hibah Pengabdian yang dikelola oleh Fakultas Ilmu Sosial dan Ilmu Politik Universitas Gadjah Mada
} 
penelitiannya di Kulon Progo, White (2016) menyelidiki perubahan lanskap generasi yang dihadapi oleh anak muda di Desa Kali Loro. Pada periode 1970an terjadi peningkatan partisipasi pendidikan pemuda berusia 15 tahun ke atas (White, 2016). Namun, masih banyak aktivitas ekonomi-mikro yang juga dilakoni di luar jam sekolah. Anak muda biasa bekerja 5.5 jam dan anak perempuan sekitar 10 jam per hari di area pertanian dan non-pertanian (Ibid, h.53 dalam Robinson (edt), 2015). Angka pendidikan meningkat memasuki awal 2000 di mana $70 \%$ penduduk berusia 16 - 18 tahun setiap pagi pergi ke sekolah. Shiraishi (1997, h.23) mengatakan bahwa perubahan ini menambah panjang masa muda dan menunda proses transisi menuju tangga kedewasaan. Selain itu, pendidikan juga ikut berperan penting dalam perpindahan usia produktif dari desa ke kota dan mengakibatkan aktivitas ekonomi di desa menjadi lesu (Nilan, 2013).

Kondisi tersebut merupakan satu gambaran yang dapat memberikan landasan kontekstual atas lengangnya kondisi jalanan di desa, barangkali juga sepinya sawah dari telapak gadis dan jejaka yang baru mekar untuk sekadar mencangkul atau main - main di atas punggung kerbau. Kota, rupanya masih dianggap sebagai tempat bermukimnya masa depan yang stabil dan gambaran kesuksesan yang representatif. Diskursus ini merambat dari generasi ke generasi, keluar masuk sebagai solusi sekaligus ancaman (ibid). Yang sudah - sudah, usia produktif bepergian, berdesakan di kapling perkotaan, dan desa diterlantarkan begitu saja, tak terbangun.

Komitmen untuk meretasnya telah dilakukan oleh berbagai pihak. Dari sudut pengambil keputusan. Legislatif mengesahkan Undang-Undang Desa Nomor 6 Tahun 2014 yang memberikan wewenang kepada entitas perangkat desa dan warganya untuk menyusun rencana pembangunan yang partisipatif. Dampak dari kebijakan ini adalah kucuran dana segar yang dapat dimanfaatkan untuk merealisasikan berbagai program yang telah direncanakan. Seolah-olah, negara menjamin kewenangan dan kebebasan bagi warga desa untuk mengelola sumber daya yang potensial untuk dikembangkan dan berdampak bagi kesejahteraan umatnya.

Kebijakan ini cukup problematis dari segi spirit yang ditawarkan dan teknis pelaksanaan. Pertama, munculnya ambiguitas atas semangat untuk menawarkan self-governing bagi pemerintah desa, namun ternyata sangat sentralistik dengan aturan yang bertubitubi (Puskapol-UI, 2016). Penyaluran dana dari pusat rawan akan praktik-praktik yang menekan desa dengan berlindung di balik redaksi Undang-Undang. Inilah pemicu problem kedua di mana pengelolaan pembangunan desa tidak partisipatif. Warga belum dilibatkan secara aktif sejak proses perancangan hingga pelaksanaan sekaligus pengawasan program.

Sementara itu, usia produktif yang bermukim di desa bergegas angkat koper dari rumah untuk mencari sumber ekonomi di kota-kota besar. Padahal mereka adalah anak anak muda berpendidikan yang potensial untuk mengelola sumber daya desa baik dengan skema Undang-Undang Desa Nomor 6 Tahun 2014, swakelola, maupun kolaborasi keduanya. Maka dari itu, partisipasi dari mereka akan berdampak pada akselerasi pembangunan karakter yang signfikan. Ini sudah dibuktikan di beberapa desa. Salah satunya adalah Desa Nglanggeran yang membangun kompleks wisata-terintegrasi dengan pemuda sebagai motor utamanya. 
Penelitian ini merupakan satu usaha untuk memperlebar peluang partisipasi anak muda dalam pengembangan desanya. Tentu saja pengembangan dari sudut pandang usia muda di mana kreativitas dan keberagaman menjadi prioritas untuk mengantisipasi keberlanjutan rencana pengembangan. Berlandaskan metode participatory action research aktivitas ini menghasilkan satu karya bersama yang disebut Sistem Informasi Potensi Kreatif Desa (SIPKADES).

Karya ini ke depannya bertindak sebagai medium untuk advokasi program pembangunan berbasis data; promosi sumber daya desa; dan pengawasan pelaksanaan program. Itu dicapai bersenjatakan kerangka pikir institutional entrepreneurship dengan menaruh interaksi antara agen dan struktur secara akur sekaligus saling kritik (Ortiz, 2010). Dinamika inilah yang menimbulkan cara, pendekatan, dan visi baru dalam berhadaphadapan dengan potensi dan tantangan yang berserak di lanksap sosial, dalam hal ini, desa.

Aktivitas ini dilakukan secara kolaboratif bersama teman-teman muda Desa Brosot Kecamatan Galur Kabupaten Kulon Progo selama kurang lebih enam bulan di sepanjang tahun 2016. Harapannya, aktivitas ini dapat membuat teman - teman muda di Desa Brosot untuk tetap menyimpan kopernya di bawah almari pakaian dalam kamarnya. Sehingga, jala jalan desa tidak terlampau lengang; tepian kali progo menjadi sibuk; dan sawahsawah tersentuh oleh jiwa-jiwa muda. Tentu saja dengan cara mereka; yang terkadang tak sempat terpikirkan oleh

${ }^{1}$ C.McDonald, 'Understanding Participatory Action Research : A Qualitative Research Methodology orang dewasa, yang biasanya bertindak sebagai pengambil keputusan.

\section{METODE}

Metode yang digunakan dalam riset ini adalah Participation Action Research (PAR). ${ }^{1}$ Sebagai bagian dari metode kualitatif, PAR berusaha merekam atau menginterpretasikan pandangan dan pemikiran subjek penelitian seobjektif mungkin tanpa manipulasi dan intervensi peneliti. Tujuan utama PAR adalah menghasilkan tindakan atau aksi yang berkontribusi pada perubahan. Idealnya PAR bersifat demokratis, berusaha melibatkan dan mendorong partisipasi semua pihak, serta melihat persamaan atau kesetaraan potensi semua pihak untuk berkontribusi. Metode pengumpulan data yang digunakan dalam PAR meliputi focus groups, participant observation, dan wawancara.

Focus groups dapat diartikan sebagai wawancara secara berkelompok. Peneliti berusaha menyediakan ruang diskusi yang kondusif sehingga semua partisipan (baik peneliti dan subjek penelitian) dapat menjalin komunikasi dengan baik. Topik diskusi sebaiknya disepakati bersama, biasanya akan berkembang seiring dengan berjalannya diskusi. Participant observation memungkinkan peneliti untuk mengamati dan terlibat dalam kondisi sosial yang terjadi di lokasi penelitian. Dalam prosesnya, peneliti tidak hanya bertugas mengamati dan mendengar, tetapi ikut aktif terlibat dalam kegiatan yang berlangsung selama pengamatan (seeing, hearing, experiencing). Sementara, wawancara adalah cara peneliti untuk mengetahui pemikiran atau pandangan

Option', Canadian Journal of Action Research, Volume 13, Issue 2, 2012, p. 34-43. 
subjek penelitian dengan kata atau cara mereka. Wawancara adalah bentuk komunikasi dua arah yang memungkinkan partisipan untuk saling bertukar ide, gagasan, dan pengetahuan.

Penelitian tindakan partisipatif (action research) (Salim,2006) merupakan penelitian dengan fokus pada subjek individu atau kelompok masyarakat yang harus diubah perilakunya sesuai dengan ideologi yang dimiliki peneliti.
Mekanismenya dapat berupa pengamatan terlibat (participant observation) bertujuan mendapatkan 'pengetahuan awal', bekerjasama dengan orang-orang lokal untuk memperbaiki kondisi masyarakat lokal. Adapun proses dari penelitian tindakan menurut Mertler (2011) yaitu terdiri atas 4 (empat) tahapan meliputi (1) tahap perencanaan, (2) tahap pengambilan tindakan, (3) tahap pengembangan dan (4) tahap refleksi. Berikut ilustrasinya:

\section{Gambar 1. Proses Penelitian Tindakan}

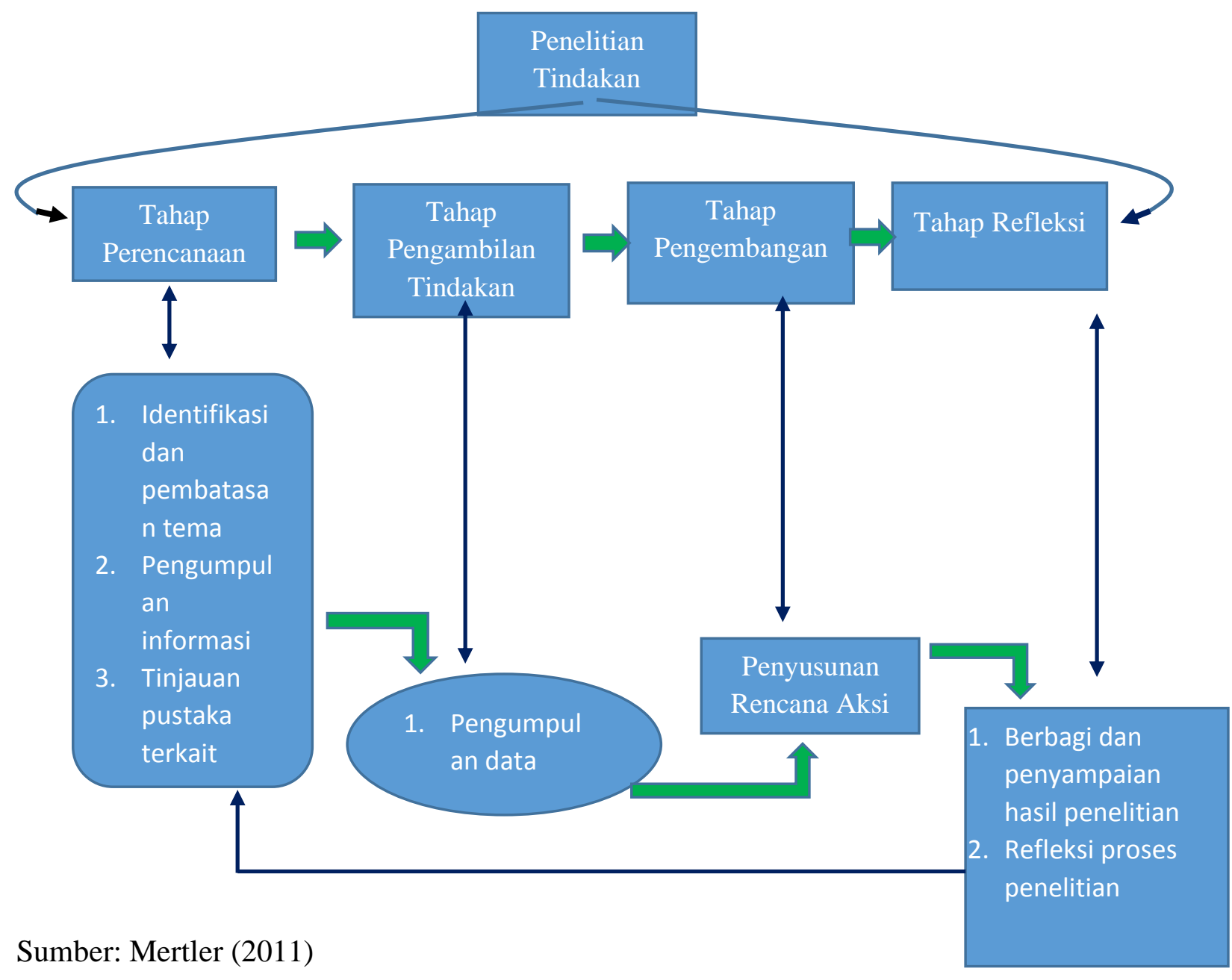

Dari Gambar 1, Johnson (dalam Mertler, 2011) melengkapi penjelasan tersebut yaitu adanya proses langkahlangkah tersebut dimaksudkan agar berfungsi sebagai panduan dalam melaksanakan penelitian tindakan. Kesembilan langkah ini harus disesuaikan dengan permasalahan atau tema penelitian 
tertentu. Pada akhirnya, penelitian tindakan ini dapat memungkinkan peneliti untuk memunculkan solusi berupa praktik terbaik dari peristiwa yang menjadi kajian penelitian.

Metode ini memungkinkan terjadinya kolaborasi sejak di awal. Dalam praktik yang ada di lapangan. Di tahap awal, peneliti dan teman-teman muda bersama-sama mengidentifikasi potensi yang ada di desanya baik terjun langsung dengan metode transect maupun dalam diskusi kelompok dengan kerangka pengetahuan lokal yang berpengaruh besar sebagai kacamata refleksif dalam melihat "apa yang sedang berlangsung." Tahapan tersebut merupakan adaptasi dari konsep PAR yang ditawarkan oleh Mertler (2011) dengan alur sebagai berikut.

\section{Gambar 2. Alur Program SIPKADES}

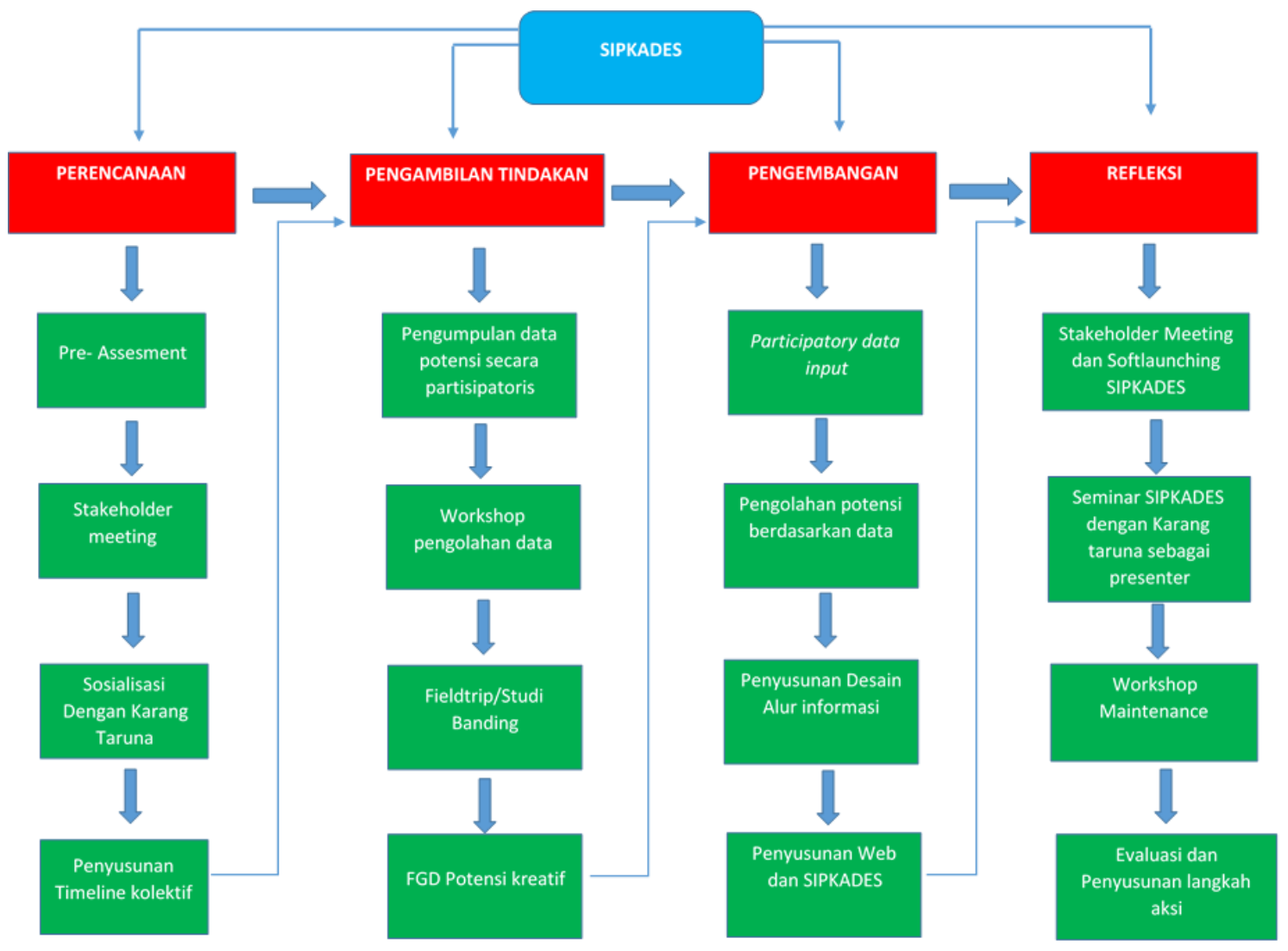

Satu hal yang menjadi penting dari penerapan metode ini bersama muda- mudi Brosot adalah proses "mengalami." Ini merupakan keunggulan sekaligus tantangan. Peneliti dapat menjadi bagian dalam satu kebudayaan tertentu yang terkadang sangat spesifik sehingga memungkinkan untuk mendapatkan kekayaan informasi yang unik. Namun, di lain sisi, ada tantangan metodologis di mana jarak yang dipangkas habis berpeluang menimbulkan intepretasi yang berat sebelah dan memposisikan partner sebagai pihak yang paling benar. Tantangan inilah yang harus diantisipasi agar aktualisasi riset partisipatif tetap sesuai 
kebutuhan dari kolaborator, namun juga tetap mempertimbangkan kemungkinankemungkinan lain yang barangkali tidak akan muncul apabila peneliti memposisikan kolaborator sebagai subjek-kebenaran dengan dalih "mengalami."

\section{INSTITUTIONAL}

\section{ENTREPRENEURSHIP : DIALOG SUBJEK DAN STRUKTUR INSTITUSI}

Aktivitas "mengalami" bersama muda mudi Brosot dikelola dengan kerangka pikir dan pendekatan institutional. Ini dilakukan mengingat semangat yang ingin ditawarkan adalah pengelolaan sumber daya desa secara efektif agar dapat menghasilkan aktivitas ekonomi-budaya yang bertautan dengan prinsip-prinsip kolektif. Ini sejalan dengan North (1990) yang menyinggung bahwa entrepreneur merupakan agen kunci dalam perubahan secara institusional. Harapannya, pendekatan ini dapat mengkerangkai usaha teman-teman muda Brosot untuk melakukan akselerasi desanya melalui proses pengakraban institusi dengan sumber daya lokal sehingga tercipta kolaborasi yang produktif di antaranya.

Kemunculan perkakas pikir institutional entrepreneurship tidak bisa lepas dari pergunjingan di antara agen dan struktur yang telah lama beredar di ilmu sosial; begitu juga dalam kajian kepemudaan di mana agensi dalam wilayah studi pemuda menjadi terma problematis yang kerap tidak akur dengan strukturalis yang percaya betul bahwa agen hanya peraga belaka atas struktur yang bercokol di tengah masyarakat (Evans, 2002; Bourdieu, 1993; Wacquant 1992). Di sudut yang lain, Kennely (2011) sepakat bahwa agen adalah subjek yang tidak sekadar menuruti apa yang dikehendaki struktur, namun juga memiliki andil dalam membentuk struktur itu sendiri, atau bahkan melawan. Permasalahan muncul ketika perlawanan agen tersebut dilakukan dengan diskursus yang dibangun oleh struktur. Dengan ini, agen atau subjek rasa-rasanya tetap tidak akan pernah luput dari panopthicon struktur besar atmosfer sosial. Bourdieu (1993) menawarkan konsep habitus dan ranah di mana agen dan struktur saling berinteraksi; kadang akur, kadang tidak, namun mereka sama-sama membangun ranah; saling merevisi dan saling melengkapi.

Perdebatan itulah yang juga menjadi dasar munculnya pendekatan institusional dalam melihat aktivitas entrepreneurship; yang membedakannya dengan pendekatan personal entrepreneurship (Krueger, 2000). Argumen dasar pendekatan institutional entrepreneurship adalah daya pengaruh aktivitas institutional memiliki andil besar dalam ranah dan aras studi entrepreneurship. North (1990, 2005 dalam Ortiz, 2010) menyampaikan bahwa institusi adalah seperangkat kompleksitas yang menyusun (baca: membatasi) struktur politik, ekonomi, dan interaksi sosial melalui pembatasan-pembatasan secara informal sekaligus aturan formal. Di lain pihak, Scott (2008: 33) berpendapat bahwa institusi adalah struktur dan aktivitas kognitif, normatif, dan regulatif yang menyediakan stabilitas serta makna dalam perilaku sosial yang terintegrasi melalui tiga pilar utama, yakni kultur, struktur, dan rutinitas. Subjek-subjek atau secara spesifik dalam studi ini disebut sebagai entrepreneur, kemudian, berada di dalam skema tersebut saling memberikan pengaruh bagi aktivitas entrepreneurship. Sebab, barangkali institusi tidak selamanya mengontrol entrepreneur, sebaliknya entrepreneur justru memberikan kontribusi 
pada aktivitas institusional (Hernekson dan Sanandaji, 2011).

Dialekika itulah yang merupakan konsekuensi logis dari perdebatan subjek dan struktur, di mana entrepreneur sebagai subjek dan institusi sebagai representasi struktur saling mempengaruhi dan menyusun makna. Dalam praktiknya, Gimenez dkk (2010 : 4) menyatakan pentingnya untuk mengidentifikasi tekstur sosial politik yang merepresentasikan lingkungan institusional tempat di mana geliat entrepreneurship hidup dan berkembang. Oleh karena itu, proses pemetaan institusi dari berbagai level merupakan satu faktor mayor di mana perbedaan karakter dan kecenderungan institusi juga memiliki interaksi yang berbeda di antara subjek pelaku entrepreneur.

Alvarez et al. (2010) dalam penelitiannya menemukan bahwa institusi informal memiliki pengaruh besar dalam jagad entrepreneurship, ali -alih institusi formal. Ini berkaitan dengan karakter kultur lebih kuat berpengaruh terhadap preferensi entrepreneur, daripada institusi formal yang berkutat pada legal-formal administratif serta aturan-aturan positivistik belaka. Namun, tetap tak bisa dipungkiri bahwa perangkat tersebut tetap memiliki andil dalam mempersulit ataupun mempermudah aktivitas entrepreneurship. North (2005) juga mengatakan bahwa lanskap institusi formal berpengaruh dalam proses penyusunan teknis entrepreneurship serta komoditas yang hendak ditawarkan kepada pasar serta mekanisme modal yang determinan.

Aras kajian kepemudaan, dalam pendekatan institutional, kemudian memposisikan pemuda sebagai subjek aktif yang melakukan negosiasi kultural dan struktural yang di tahap selanjutnya menjadi agen kunci melalui aktivitas entrepreneurship. Mereka, dalam kondisi precarity yang penuh kerentanan, berusaha untuk menjawab tantangan kompetisi di konteks liberalisasi-ekonomi melalui akumulasi modal sumber daya lokal, yang khas dan cenderung dilakukan atas dasar kolektivitas.

Praktik bersama dengan temanteman muda Brosot dalam berinteraksi dengan institusi formal maupun informal mensyaratkan pendekatan institusional yang peka. Di dalam prosesnya, temanteman muda diharuskan bernegosiasi dengan kondisi terkini dari institusi formal yang direpresentasikan oleh perangkat desa dan karang taruna sebagai turunannya di ranah kepemudaan serta menyesuaikan dengan institusi informal yang banyak bersinggungan dengan kultur serta routine yang dijalani oleh pemuda Desa Brosot. Sebuah taruhan yang tidak murah barangkali, ketika kompetisi semakin menjadi-jadi, teman-teman muda Brosot justru berada di dalam desa, berusaha mengembangkan apa yang ada.

\section{MODAL SOSIAL DI ERA DIGITAL}

Williamson (2000) menawarkan sebuah tesis akan relevansi dari lembaga informal yang secara kultur dan relasi sosial memiliki daya lenting spontan yang tangguh. Perwujudannya terletak pada jejaring yang mengikat secara kebudayaan. Inilah yang menjadi bekal teman-teman muda Brosot untuk memalingkan rupa pada kompetisi rasionalitas-instrumental yang banyak dilakoni pemuda sebagai akibat dari gemerlap megapolitan. Jejaring menurut Brass (1992) didefinisikan sebagai sebuah paket hubungan antar aktor yang oleh Burt (1992) dilengkapi dengan penambahan variabel kesempatan untuk mengakses finansial dan sumber daya manusia di 
dalamnya. Konsep jejaring yang demikian sebetulnya telah dibahas jauh-jauh hari oleh Bourdieu (1990) melalui modal sosial, sebagai bagian dari institusi sosial seperti kepercayaan, norma dan jaringan yang dapat meningkatkan efisiensi masyarakat dengan memfasilitasi tindakan-tindakan bersama yang terkoordinasi.

Satu hal yang menarik dari Bourdieu (1990) adalah mekanisme pertukaran modal yang ada di dalam ranah (institusi). Modal sosial yang melekat di dalam masyarakat memiliki kesempatan untuk bertukar menjadi modal ekonomi, pengetahuan, bahkan simbolis. Ini tergantung pada praktik yang dilakukan dalam mengelola modal yang di miliki dan konteks yang "berlaku" dalam lokasi kultural tertentu. Sementara itu, generasi millenia tumbuh dengan kecenderungan untuk membangun jejaring melalui aktivitas digital. Menurut Palfrey dan Gasser (2008: 3) kondisi ini merupakan gejala digital natives yang terkoneksi satu sama lain; berbagi kultur yang sama dan termediasi melalui teknologi digital dalam segala aspek kehidupan seperti pertemenan; interaksi sosial; dan aktivitas sipil. Ini adalah sebuah kultur yang menunjukkan satu identitas komunal melalui praktik berbagi informasi yang tipikal. Berjejaring, kemudian menjadi satu keniscayaan yang dialami oleh generasi digital untuk menjalani kehidupan sehari-hari yang didominasi oleh basis teknologi informasi (Gasser, 2008: 20).

Modal sosial, dengan ini, menyaru ke berbagai wujud, salah satunya adalah jejaring digital. Fungsi arus informasi, komunikasi, dan koordinasi kemudian beralih ke jaringan internet. Inilah ranah yang lebih akrab dengan teman-teman muda alih-alih komunikasi tradisional yang intens dan menimbulkan prasyarat ruang fisikal. Praktik institutional entrepreneurship yang dijalani oleh teman -teman muda, tentu saja, perlu mempertimbangkan modal sosial yang demikian sebagai salah satu bagian praktikal dan strategis dalam mengelola sumber daya baik melalui mekanisme pertukaran modal maupun akumulasi sumber daya.

\section{BROSOT : MATA AIR DI TEPIAN SUNGAI PROGO}

Desa Brosot tergabung dalam wilayah Kecamatan Galur, Kabupaten Kulon Progo di ujung selatan Provinsi Daerah Istimewa Yogyakarta. Pemisah Desa Brosot dengan Bantul ditandai oleh bentangan Sungai Progo, yang juga merupakan aset budaya yang signifikan bagi eksistensi Brosot. Sebabnya, Sungai Progo menyimpan berbagai sumber cerita rakyat yang berdetak sebagai denyut nadi kehidupan di sekitarnya. Desa ini memiliki 98,98 ha tanah pertanian; 67,39 ha tanah kering dan 63,8 permukiman. Komposisi ini dipertimbangkan sebagai salah satu dari sekian data yang memuat kepemilikan sumber daya desa. Selain itu, Desa Brosot merupakan pintu masuk sebelah selatan menuju Provinsi DIY. Saat ini tengah dibangun Jalan Lintas Selatan sebagai jalur protokol lalu lintas utama Pulau Jawa. Dengan ini, Brosot merupakan satu titik strategis yang perlu penyikapan tertentu sebagai respon atas peluang perubahan lanskap sosial-ekonomi di sekitarnya.

Potensi unggulan yang ditawarkan oleh Desa Brosot adalah kekayaan budaya yang menyaru dalam berbagai wujud antara lain atraksi reog, kirab budaya, dan pertunjukkan jathilan. Di beberapa dusun bahkan memiliki aset seperangkat gamelan yang dikelola oleh warga desa. Kondisi tersebut merupakan satu dari sekian alasan 
yang melandasi pendaulatan Desa Brosot sebagai salah satu desa budaya di Kabupaten Kulon Progo melalui Surat Keterangan Gubernur Nomor 325/KPTS/1995 tentang Pembentukan Desa Bina Budaya. Dicanangkannya Desa Brosot sebagai desa budaya ini bertujuan untuk menjadikan Desa Brosot sebagai wahana bagi pembinaan, pengembangan dan pelestarian segala potensi budaya yang ada, sehingga diharapkan dapat terwujud suatu tatanan masyarakat yang harmonis yang mau dan mampu menghargai nilainilai budaya yang tumbuh dan berkembang di Desa Brosot.

Konsekuensi logis dari legal-formal tersebut adalah pendirian satu struktur dalam desa yang khusus mengawal implementasi Desa Budaya. Hitam di atas putih, kondisi ini sangat menguntungkan pihak desa karena ada legitimasi yang menguatkan. Namun, pada praktiknya justru merupakan satu tantangan tersendiri. Dalam satu kesempatan FGD, kepala desa budaya mengatakan :

Desa Budaya kesulitan untuk menggunakan anggaran karena provinsi terlalu ketat dalam mengatur pengeluaran, sering meminta revisi anggaran yang sekiranya mereka menganggap itu kurang penting.

(FGD dengan perangkat Desa, 9 Juni 2016).

Di lain pihak, Dana Desa yang sebenarnya dapat diandalkan untuk memfasilitasi aktivitas warga justru menemukan tantangannya sendiri. Hal ini diungkapkan oleh Pelaksana Tugas Kepala Desa Brosot sebagai berikut

Masalah anggaran dana desa sangat ketat pengaturannya dari pusat. Setiap 3 bulan sekali direview. Kadang mereka menganggap kegiatan tidak penting dan menuntut kami merevisi anggaran.
(FGD dengan perangkat Desa, 9 Juni 2016).

Inilah tantangan dari beberapa potensi yang dimiliki Brosot. Regulasi yang sentralistik dan barangkali tak terlalu efektif. Kondisi ini senada dengan laporan yang ditulis oleh Puskapol UI (2016) bahwa implementasi Dana desa tidak sepenuhnya mempermudah akselerasi pembangunan desa. Sementara itu, partisipasi dari warga juga dipertanyakan. Dalam kasus ini, tentu saja pemuda di Desa Brosot. Memang, partisipasi yang aktif dan menyeluruh tidak lalu bergantung pada perangkat desa semata, namun ada beberapa prasyarat sosiokultural yang perlu dibangun. Salah satu sesi FGD dengan pemuda Desa Brosot menguak beberapa tantangan yang berkaitan dengan pengelolaan Desa.

Acara ini (SIPKADES) bagus sekali dan perlu juga mungkin dijadikan momentum untuk menghidupkan kembali karang taruna tunas karang kemuning yang sempat mati dan bisa kembali difasilitasi desa. Sekarang itu vakum, mungkin sejak tahun 2012 atau 2011. Waktu itu karena Ketuanya menikah, terus tidak ada regenerasi, padahal anak - anak brosot ini potensial tapi karena tidak ada wadah jadi tidak pernah dilibatkan. Misalnya saja, saya tuh selalu protest kenapa desa budaya itu yang mengelola orang - orang tua, padahal banyak anak yang potensinya bagus - bagus. Nah dari itu sebenarnya kita butuh karang taruna sebagai organisasi yang formal dan resmi sehingga bisa dipercaya. Gitu sih.

(FGD dengan Muda - Mudi Brosot, 8 November 2016).

Karang taruna, sebagai salah satu organisasi legal yang diakui negara memang berperan strategis sebagai kanalkanal inisiatif bagi program-program pemerintah. Persoalan yang dihadapi oleh Desa Brosot adalah vakumnya kegiatan 
Karang taruna selama hampir lima tahun. Ini diakui pula oleh pengelola Karang Taruna Kabupaten Kulon Progo bahwa Brosot merupakan salah satu Desa yang menghadapi ketidakaktifan Karang taruna. Barangkali pula, inilah yang menyebabkan tidak dilibatkannya pemuda dalam aktivitas implementasi Desa Budaya.

Situasi dan kondisi pemuda di wilayah Desa Brosot ada pada lemahnya komunikasi antar pemuda 10 (sepuluh dusun). Limitasi pemuda salah satunya ada pada sisi waktu yaitu mereka masih dalam posisi dan status sebagai pelajar atau mahasiswa sehingga konsentrasi pada peningkatan kualitas diri (pendidikan). Sementara itu ada pemuda yang telah memasuki 'dunia kerja' sehingga komunikasi dan keterlibatan mereka dalam aktivitas kepemudaan maupun desa juga minimal. Kondisi ini merupakan gejala transisional yang dialami oleh kaum muda di mana mereka mulai beranjak dari ranah domestik ke aktivitas publik dengan tanggungjawab tertentu.

Apa yang dihadapi oleh pemuda di

Desa Brosot dalam pendekatan institutional merupakan tantangan yang cukup besar. Pasalnya, secara institusi formal, keberadaannya tidak terlalu kuat mengingat karang taruna tidak aktif sehingga mereka mengalami kekosongan saluran. Di lain sisi, secara informal mereka tidak berjejaring satu sama lain. Hal ini juga diungkapkan oleh salah satu pengurus karang taruna yang terdahulu bahwa pemuda Brosot tidak memiliki kebiasaan untuk berkumpul karena tidak ada satu aktivitas atau wadah yang "memberikan-alasan."

Kolaborasi yang dilakukan bersama peneliti adalah sebuah usaha untuk memunculkan inisiatif dan menjawab tantangan-tantangan tersebut.
Pendekatan yang dilakukan berkiblat pada potensi-potensi yang ada di Desa Brosot dan sebisa mungkin melibatkan banyak kalangan. Seperti yang diungkapkan oleh North (2005) bahwa institutional entrepreneurship adalah pendekatan yang menitikberatkan pada mobilisasi kelompok sosial untuk secara bersamasama mengembangkan semangat kooperatif dan dalam beberapa kasus mereka perlu memobilisasi agen kunci yang memiliki akses besar terhadap sumber daya. Secara garis besar, inilah yang dilakukan dalam skema kolaboratif antara peneliti dan teman-teman muda brosot.

\section{SIPKADES : PENGELOLAAN POTENSI BERBASIS INSTITUSI}

Sistem Informasi Potensi Kreatif Desa (SIPKADES) adalah satu karya kolaboratif yang dikelola dengan harapan akan meretas tantangan pembangunan di Desa Brosot sekaligus menguatkan peran pemuda dalam proses perancangan program pengembangan sampai pada pengawasannya. SIPKADES berisikan database potensi desa yang ditampilkan dalam website. Data yang dikelola merupakan hasil dari identifikasi yang dilakukan oleh teman - teman muda Brosot melalui pemetaan langsung sebagai sumber data primer dan dokumen pemerintah desa sebagai sumber data sekunder. Data tersebut harapannya dapat memperkuat argumen teman-teman muda untuk mengintervensi perancangan program kepada otoritas desa. Keputusan untuk membuat website dilandasi oleh kultur berjejaring yang mampu menjangkau akses serta sumber daya yang lebih luas. Harapannya, SIPKADES dapat menyentuh banyak kalangan dan ikut berpartisipasi dalam usaha untuk mengelola potensi. 
Pelaksanaan program ini dilakukan dengan FGD bersama teman-teman muda, yang berfungsi sebagai satu mekanisme memetakan kondisi mereka dari berbagai sisi (sosial, politik, ekonomi, dan budaya). Selain itu, dinamika yang berjalan kemudian justru menghasilkan kecenderungan teman muda Brosot dalam merefleksikan desanya sendiri. Inilah data awal yang menjadi pijakan untuk langkahlangkah selanjutnya. Di tahap kedua, peneliti dan teman-teman muda Brosot mengunjungi Desa Nglanggeran. Desa ini dipilih karena telah berhasil mengelola potensi desa dengan sumber daya jiwa muda dan memiliki kapasitas untuk melakukan intervensi kebijakan pemanfaatan sumber daya alam sebagai potensi wisata di Kabupaten Gunung Kidul. Di kesempatan ini, sesuai North (2005) bahwa institutional entrepreneurship adalah soal membangun jejaring informal dan membangun aliansi dengan aktor yang lain. Tentu saja, selain itu, ada pengetahuan yang relevan untuk dijadikan pertimbangan sebagai bekal memandang satu sumber daya sebagai potensi penting yang "dapat" dikembangkan. Tahap pertama dan kedua menghasilkan satu rancangan database potensi Desa Brosot. Data itu kemudian mengalami proses triangulasi. Peneliti dan teman Brosot berkolaborasi keliling desa, mengujungi setiap potensi yang telah terdata sekaligus sowan kepada beberapa sesepuh desa untuk membicarakan satu dua hal. Tantangan muncul ketika usaha tersebut belum mampu menjangkau sepuluh dusun yang tersebar di Desa Brosot. Pada tahap ini, teman - teman muda yang terlibat kemudian diperluas sehingga semakin banyak energi yang diajak mengelola SIPKADES.

Beberapa teman muda kemudian menginisiasi pertemuan rutin dari setiap dusun. Masing - masing perwakilan diminta bersama-sama untuk melakukan pendataan secara mendetail perkara potensi-potensi yang berserak di wilayahnya sendiri. Hasil kerja tersebut dikelola bersama dan dikategorikan ke dalam beberapa jenis potensi, yang antara lain potensi alam, pertunjukkan, peninggalan bersejarah, dan kerajinan. Inilah akar dari SIPKADES di mana data dari potensi tersebut dituliskan secara naratif untuk kemudian dijadikan sebagai "pernyataan" bersama yang memperkuat proses advokasi program pengembangan. Di dalamnya juga termuat rencana arah kreatif dari setiap potensi sehingga proyeksi program dapat diduga baik dari segi kebutuhan maupun keuntungan. Tampilan dari formulasi potensi tersebut disusun interaktif dalam wadah digital di mana setiap orang di wilayah desa dapat mengaksesnya dan memberikan masukan secara berkala sebagai bagian dari partisipasi.

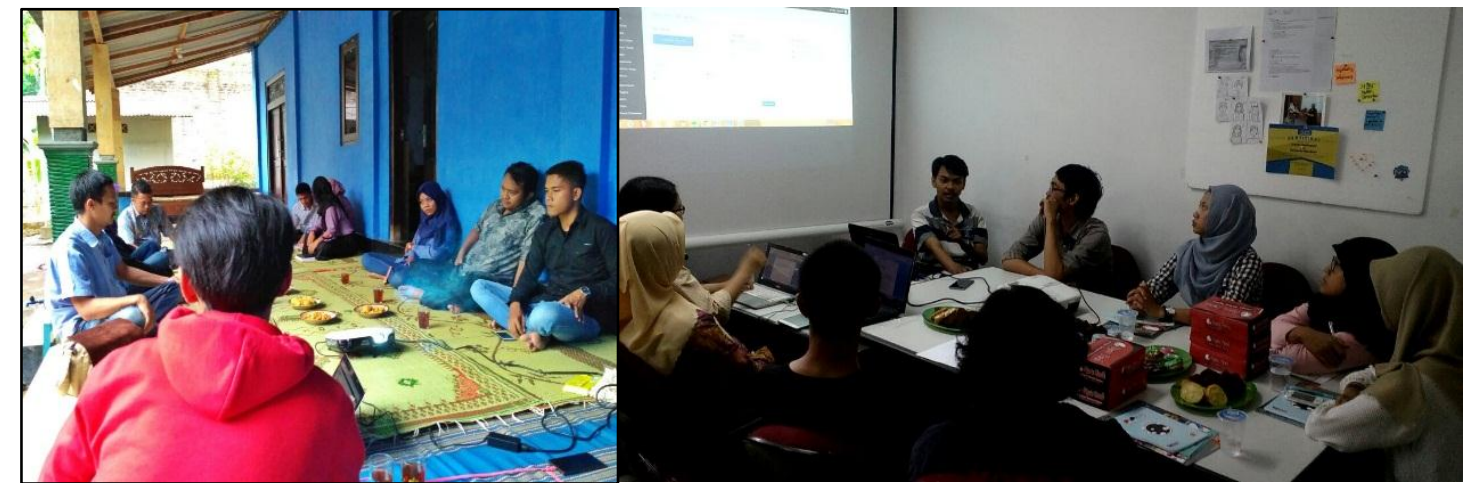

Gambar 3. Proses Pengumpulan Database Potensi 
Usaha ini berlangsung dengan satu motif sosial yang belakangan dikhawatirkan pudar dari kalangan teman - teman muda di Indonesia (Tadjuddin, 2010). Terminologi kuno yang barangkali tak lagi laku dan hanya terdengar di antara generasi $x$ yang sudah tak lagi produktif. Pemuda di zaman serba digital seperti sekarang ini jarang sekali menyebut istilah gotong royong. Padahal barangkali, praktiknya tetap berlangsung namun dengan diksi yang berubah dan mengalami pergerseran maksud. Dalam trayektori ilmu sosial, Gotong Royong lebih dikenal sebagai modal sosial yang memang kurang populer dibanding istilah Jejaring Sosial (ibid).

Tadjuddin $(2010: 7)$ mendefinisikan modal sosial sebagai serangkaian nilai atau norma informal yang dimiliki bersama anggota kelompok yang memungkinkan terjalinnya kerjasama dan saling tanggungjawab. Ini sejalan dengan Fukuyama (1995) yang mengilustrasikan modal sosial sebagai nilai-nilai trust dan believe yang melekat dalam faktor kultural. Lebih jauh Fukuyama (1995) dalam Tadjuddin (2010) menerangkan bahwa asosiasi dan jaringan sosial lokal mempunyai dampak positif bagi peningkatan kesejahteraan ekonomi dan pembangunan pada aras lokal. Inilah yang dipraktikkan oleh teman-teman muda Brosot dalam skema institutional entrepreneurship melalui jalur informal (baca : kultural). Bangunan institusi sebagai kumpulan dari aksi-aksi aktor disusun dengan pondasi modal sosial yang terlanjur melekat dalam atmosfer "khas" desa yang dekat. Kecurigaan melekatnya (embedded) modal sosial dalam komunitas mereka muncul perlahan-lahan ketika aktivitas kumpul-rutin tiap dusun mendorong temanteman muda untuk menghidupkan kembali karang taruna yang sempat vakum selama lima tahun. Barangkali, ketika modal sosial bukan sesuatu yang melekat dalam satu komunitas sebagai keniscayaan, maka tanggung jawab dan kebersamaan tidak senantiasa muncul dalam kondisi-kondisi yang di luar routine.

SIPKADES sebagai sebuah institusi informal yang relatif baru, di tahap ini, melakukan perjalanan menuju formalisasi institusi lawas yang memiliki posisi legitimasi legal-formal. DiMaggio (1988 : 14) berujar bahwa institusi baru muncul ketika aktor yang tergorganisasi dengan sumber daya yang mencukupi memiliki kapasitas untuk merealisasikan kepentingan bersama dengan nilai-tinggi. Aksi konkret yang dilakukan dalam pandangan Battilana (2006) lihat juga Beckert (1999) dan Fligstein (2001) sebagai kemampuan agen untuk memobilisasi sumber daya dan aktor yang lain. Dalam pandangan ini, aktor-aktor yang bergerak dan mempengaruhi perubahan institusional memiliki ketrampilan-sosial untuk beradaptasi dengan kondisi kultural dan struktural yang sedang berlangsung. Institutional, di tahap ini, bukan lagi sekadar "entrepreneurship" yang dilakukan secar berbondong bondong dengan kendaraan institusi. Alih alih, sebagai kumpulan tindakan yang membentuk praktik untuk menggerakan komunitas ke arah pengembangan kolektif. (Ortiz, 2010).

Teman-teman Muda Brosot melalui SIPKADES dan proses identifikasi potensi desa menunjukkan gelagat yang optimistik bahwa pemuda sebagai kategori sosial tidak melulu terkontrol secara kebudayaan oleh determinasi institusional. Sebaliknya, mereka menunjukkan bahwa jejaring yang lentur justru membawa ikatan-ikatan yang 
kendur, kembali mengencang seiring dengan pengalaman dan pengetahuan yang menyejarah dilakoni bersama dalam sebuah lingkar generasi yang serupa (Lihat Mannheim, 1952). Kerangka pikir institutional entrepreneurship, dalam hal ini, bekerja sebagai solusi yang menghubungkan kekhawatiran masa depan sebagai tantangan dengan potensi lokal sebagai peluang yang memungkinkan untuk mengambil posisi sebagai agen perubahan.

Praktik institusional yang serupa bukannya tidak menuai perdebatan. Terminologi institusi sendiri dipahami sebagai seperangkat aturan formal (North, 1990) yang dipertegas oleh Powell (1991) sebagai struktur regulasi, agensi pemerintahan, hukum, pengadilan, dan profesionalitas. Zucker (1977) bahkan menuliskan institusi sebagai perwujudan logis atas praktik hukum dan regulasi. Dengan ini, institusi hanya sanggup didekati dengan objektivitas rasionalinsturmental (Powell, 1991 dalam Bruton 2010). Di sisi yang lain, Alvarez dan Urbano (2011) mempertimbangkan institusi informal seperti kultur, norma sosial, dan representasi entrepreneur, model pelaku entrepreneurship, dan "kekhawatiran" sebagai determinasi signifikan atas pendekatan institutional. Anderson dan Jack (2002) bahkan menyebutkan bahwa jejaring sosial sebagai konfigurasi relasi aktor memiliki kapasitas untuk membangun persepsi komunitas atas aktivitas entrepreneurship itu sendiri. Di titik ini, ambiguitas terasa semakin tebal seiring dikotomi informal dan formal sebagai konsekuensi logis dari pendekatan institusional semakin terkutub. Aktor yang menjalani aktivitas entrepreneurship justru luput dari skema analisis.
Belajar dari teman-teman Brosot, institutional entrepreneurship tidak secara tegas membedakan institusi formal dan informal. Memang, pada praktik yang berlangsung, institusi informal mengambil peran yang lebih tebal dalam menyusun praktik entrepreneurship melalui pengelolaan informasi jangka panjang. Hal ini senada dengan penelitian Alvarez (2011) yang dilakukan di Rusia bahwa institusi informal memiliki pengaruh yang lebih kuat jika dibandingkan peran institusi formal dalam meningkatkan aktivitas institutional.

SIPKADES yang dimulai dengan modal sosial berkendaraan institusi informal di tahap tertentu memiliki pengaruh yang kuat untuk menghidupkan kembali karang taruna sebagai sumber daya manusia yang strategis. Padahal, karang taruna di alur struktur perangkat desa berada langsung di bawah Koordinasi Kepala Desa. Idealnya, kehadiran organisasi tersebut dikelola dan dirawat oleh perangkat desa. Jejaring yang dimiliki oleh SIPKADES kemudian memiliki kapasitas untuk mengambil alih peran tersebut. Namun, di lain sisi SIPKADES tidak mengantongi legal-formal untuk mengakses sumber daya yang disokong oleh pemerintah melalui Dana Desa dan Dana Kebudayaan. Untuk itulah proses formalisasi menjadi satu faktor strategis yang perlu ditempuh oleh teman-teman muda Brosot agar potensi yang terpetakan dan terencanakan dapat diaktualisasikan dengan akumulasi sumber daya baik dari Karang Taruna itu sendiri maupun modal sosial-politik yang melekat dalam organisasi tersebut.

\section{KESIMPULAN}

SIPKADES memberikan beberapa optimisme yang penting baik bagi praktik 
pengetahuan maupun pengembangan teman-teman muda secara konkret. Pertama, dari segi pengetahuan, praktik kolaboratif yang dikelola di antara peneliti dan teman-teman Muda dapat menghasilkan satu karya yang berbasis potensi lokal. Ini merupakan perwujudan emansipatoris di mana teman - teman muda tidak lagi dilihat sebagai objek penelitian semata, melainkan partner untuk mencari solusi yang tepat bagi kekhawatiran yang melekat dalam komunitas. Kedua, pendekatan institutional memungkinkan cara pandang yang terbuka dalam menyikapi proses akumulasi sumber daya yang negosiatif dan perlu mempertimbangkan kecenderungan institusional. Ketiga, teman-teman muda tidak perlu lagi dipandang sebagai korban dari tingginya kompetisi hingga tidak memiliki kepedulian pada aktivitas lokal yang sebenarnya potensial.

Optimisme tersebut tentu saja bersanding dengan tantangan yang perlu dihadapi dalam studi serupa. Metode participatory research action mensyaratkan peneliti untuk dapat menjaga jarak sekaligus berada begitu dekat dengan partner agar dapat memetakan peluang dan tantangan secara utuh. Ini berdampak terhadap implementasi pendekatan institutional yang mensyaratkan penglihatan jeli pada kecenderungan peraturan dan nilai yang berada dalam komunitas-partner. Jika tantangan tersebut terkelola dengan baik, maka optimisme yang potensial didapatkan dari metode dan pendekatan ini untuk bekerjasama dengan teman-teman muda akan berlipat ganda.

\section{DAFTAR PUSTAKA}

Alvarez, C., Urbano, D., Corduras, A., \& Navarro, J. (2011). Environmental conditions and entrepreneurial activity: A regional comparison in Spain. Journal of Small Business and Enterprise Development, 18(1), 120-140.

Anderson, A. R., \& Jack, S. L. (2002). The articulation of social capital in entrepreneurial networks: a glue or a lubricant?. Entrepreneurship \& Regional Development, 14(3), 193210.

Battilana, Julie, and Thomas D'Aunno. 2009. "Institutional Work and the Paradox of Embedded Agency." Pp. 29-58 in Institutional Work, edited by Thomas Lawrence, Roy Suddaby, and Bernard Leca. Cambridge: Cambridge University Press.

Beckert, J. (1999). Agency, entrepreneurs, and institutional change: The role of strategic choice and institutionalized practices in organizations. Organization Studies, 20(5), 777-799.

Bourdieu, Pierre. 1990. The Logic of Practice. Stanford: Stanford University Press.

Burt, R. (1992). Structural holes. Cambridge, MA: Harvard University Press.

DiMaggio, P.J. (1988). Interest and agency in institutional theory. In L.G. Zucker (Ed.), Institutional patterns and organizations (pp. 3-21). Cambridge, MA: Ballinger.

Fligstein, N. 2001. Social skills and the theory of fields. Sociological Theory, 19(2): 105-125.

Fukuyama, Y, 1995, Trush: The Social Virtues and the Creation of Prosperity, London: Hamish Hamilton Affairs, 3, 187-203 Kennelly, Jacqueline. 2011. Citizen Youth : Culture, Activism, and Agency in 
A Neoliberal Era. New York :

Palgrave Macmillan.

Krueger, N. (1993). Impact of prior

entrepreneurial exposure on

perceptions of new venture

feasibility and desirability.

Entrepreneurship: Theory and

Practice, 18(1), 5-21.

Mannheim, Karl. 1952. Essays on the

Sociology of Knowledge. London:

Rou

North, D. C. (1990). Institutions, institutional change and economic performance. Princeton, NJ:

Princeton University Press.

North, D. C. (2005). Understanding the process of economic change. Princeton, NJ: Princeton University Press.

Palfrey, John and Urs Gasser. 2008. Born

Digital : Understanding The First Generation of Digital Natives. New York : Basic Books.

Parker, Lyn and Nilan, Pam 2013. Adolescents in Contemporary Indonesia, London \& New York: Routledge.

Suzanne Naafs \& Ben White. 2012.

"Intermediate Generations:

Reflections on Indonesian Youth Studies." The Asia Pacific Journal of Anthropology Vol. 13, No. 1, February

White, Ben. 2016a. Generation and Social Change: Indonesian Youth in Comparative Perspective in Kathryn Robinson (eds), Youth Identities and Social Transformations in Modern Indonesia. Leiden, Boston : Brill. 